Красинский Владислав Вячеславович, кандидат юридических наук

Источник опубликования: Красинский В.B. Проблемы легитимации власти после президентских выборов в Иране // Современное право. 2010. № 1. С. 138-143; www.krasinskiy.ru

(C) В.В. Красинский

\title{
ПРОБЛЕМЫ ЛЕГИТИМАЦИИ ВЛАСТИ ПОСЛЕ ПРЕЗИДЕНТСКИХ ВЫБОРОВ В ИРАНЕ
}

12 июня 2009 г. в Исламской Республике Иран состоялись президентские выборы². Победу одержал Махмуд Ахмадинежад, получивший 62, 63\% голосов избирателей ${ }^{3}$. Его главный оппонент Мир Хуссейн Муссави набрал 33, 75\% голосов. Несмотря на ощутимый перевес голосов в пользу Ахмадинежада, 13 июня 2009 г. после обнародования результатов выборов Муссави отказался признать легитимность народного волеизъявления и призвал своих сторонников к акциям протеста ${ }^{4}$. Уличные выступления сторонников Муссави переросли в массовые беспорядки, в ходе которых погибли, по официальным данным 19 человек, 457 человек было арестовано, около 40 полицейских получили ранения 5 .

Сценарий произошедших событий разворачивался в духе классических «цветных» революций, направленных на захват представителями оппозиции государственной власти и политическую переориентацию своих стран на Запад. Несмотря на непривычную отстраненность и сдержанную позицию руководства Соединенных Штатов в отношении протестных акций в Тегеране, очевидно, что попытка смены политического режима в Иране (Regime Change) осуществлялась в полном соответствии с

${ }^{1}$ Красинский Владислав Вячеславович кандидат юридических наук, эксперт Российского общественного института избирательного права (РОИИП).

2 По данным Министра внутренних дел Ирана Садека Масули, явка на выборах оказалась рекордной и составила $85 \%$ из 46,2 миллиона избирателей, внесенных в списки. В связи с высокой активностью граждан избирательные органы (по иранскому законодательству полномочия по организации и проведению выборов возложены на МВД) были вынуждены неоднократно продлевать время работы избирательных участков. См. Рос. газ. 2009. 15 июня.

3 Президент Исламской Республики Иран избирается на 4 года по мажоритарной системе абсолютного большинства (для победы требуется получить более 50\% голосов участников выборов). Если кандидат на должность Президента не набирает необходимого количества голосов избирателей, проводится повторное голосование (т.н. «второй тур»). Президент Ирана возглавляет исполнительную власть и представляет Исламскую Республику за ее пределами.

${ }^{4}$ Целью настоящей статьи не является доказательство или опровержение фальсификаций итогов голосования на ряде избирательных участков в Иране. Автор предпринял попытку проанализировать события, произошедшие в Тегеране после обьявления результатов президентских выборов, в контексте «цветных» революций.

5 См. Рос. газ. 2009. 23 июня. По сведениям Исламской революционной организации моджахедов иранского народа, поддерживающей Муссави, в результате беспорядков погибли 43 человека, из которых 30 демонстрантов в Тегеране. 
американской программой «поддержки демократии», предусматривающей осуществление контроля за формированием выборных институтов власти в «демократически незрельх странах» ${ }^{1}$.

Упомянутая процедура «поддержки» демократии предполагает «силовой» и «конституирующий» этапы смены политического режима² .

«Силовой» этап начинается с митингов оппозиции против нарушений законодательства о выборах. Организаторами поднимается тема фальсификации результатов выборов и использования кандидатами «административного ресурса» (именно так начинались «щветные» революции в 2000 г. в Сербии, в 2003 г. в Грузии, в 2004 г. в Украине, в 2005 г. в Кыргызстане, в 2008 г. в Монголии, в 2009 г. в Молдавии и Иране). По мере вовлечения в акции протеста все большего количества участников возникают призывы к продолжению демонстраций и приданию протестным акциям бессрочного характера, осуществляется блокирование важнейших государственных учреждений и органов государственной власти. «Спонтанные» акции гражданского неповиновения общественности организованно перерастают в массовые беспорядки ${ }^{3}$. Выдвигается ультиматум властям с требованием добровольной отставки и немедленной передачи власти лидерам оппозиции.

«Конституирующий» этап оппозиционной борьбы связан с избирательной технологией, позволяющей легально захватывать государственную власть и менять политический режим. Речь идет о так называемом «внешнем голосовании». Как правило, данная технология эффективно используется после официального объявления результатов выборов. Поражение на выборах объясняется массовыми нарушениями, допущенными кандидатом-оппонентом, результаты обжалуются в судебном порядке, распространяется обращение к мировой общественности (в лице США и ЕС) с просьбой о непризнании результатов выборов. При этом народное волеизъявление

1 Не случайно в Стратегии Национальной Разведки Соединенных Штатов Америки, одобренной Законом Конгресса о реорганизации деятельности специальных служб и предотвращении терроризма 2004 г., закреплена стратегическая миссионерская задача США содействовать развитию демократии и поддерживать миролюбивые демократические государства.

${ }^{2}$ См.: Красинский В.В. Выборы как механизм захвата политической власти и реализации иностранной внешней политики // Военно-юридический журнал. М.: ИГ Юрист, 2006. № 3. С. 15 21.

${ }^{3}$ По свидетельству очевидцев, провокационную роль в организации массовых беспорядков в Тегеране сыграли «Исламский фронт участия Ирана» и признанная ЕС и США в качестве террористической «Исламская революционная организация моджахедов». См. Рос. газ. 2009. 15 июня. 
технически подменяется внешним признанием результатов выборов. Например, США заранее объявляют, что выборы нелигитимны и указывают, какой результат будет признан законным ${ }^{1}$.

Примером могут служить выборы Президента Югославии в 2000 г. Еще до выборов официальные лица США обвиняли югославское правительство в фальсификации выборов. Уже в день выборов, до подсчета голосов, Демократическая Оппозиция Сербии (ДОС) объявила о победе своего кандидата. Никаких оснований для этого не было. Оппозиция и не собиралась признавать выборы, какими бы ни были их результаты. Аналогичная технология был использована 21 ноября 2003 г. как повод для «революции роз», когда Госдепартамент США объявил результаты выборов в парламент Грузии сфальсифицированными. «Внешнее голосование» состоялось и 21 ноября 2004 г., когда В. Ющенко попросил страны ЕС и США не признавать итоги украинских выборов. В июне 2009 г. данная технология была успешно апробирована кандидатом в Президенты Ирана Мир-Хуссейном Муссави. До установления итогов голосования и обнародования результатов выборов Муссави уверенно заявил о своей победе на выборах, а после объявления Центральной избирательной комиссией Ирана официальных результатов выборов проигравший Муссави отказался признавать их легитимность ${ }^{2}$. Немаловажную роль в дестабилизации политической обстановки в стране и углублении кризиса сыграла открытая поддержка Муссави со стороны Президента Франции, федерального канцлера Германии, Премьер-министра Израиля, Госдепартамента США, МИД Великобритании, Европарламента, Еврокомиссии и Совета Европы.

Наряду с классическими признаками «цветных» революций зеленый «иранский» вариант имел особенности. Во-первых, организация и проведение «цветной» революции в Иране осуществлялись с учетом религиозного фактора. Его игнорирование в теократическом государстве невозможно, поскольку шиитское духовенство оказывает заметное воздействие на политическую систему иранского общества (доктрина «Welayate Fagih»). Так, кандидатуры на выборные должности утверждаются Советом стражей конституции, половина должностей которого замещается представителями высшего духовенства Ирана. 20 мая 2009 г. Совет стражей конституции опубликовал список зарегистрированных кандидатов на должность Президента

${ }^{1}$ См.: Кузьмин В. Роль США в осуществлении «цветных революций» в зарубежных странах // Зарубежное военное обозрение. 2008. № 9 (738). С. 9-18; Кара-Мурза С.Г. Экспорт революции. Ющенко, Саакашвили... М.: Изд-во Алгоритм, 2005. С. 254, 260. Для критики существующих государственно-властных институтов, принижения значения демократических традиций и политических процессов в государстве, проводящем выборы, США и финансируемыми ими международными организациями (Парламентская Ассамблея ОБСЕ, БДИПЧ ОБСЕ, Парламентская Ассамблея Совета Европы, Европейский парламент, Парламентская Ассамблея НАТО) используется отказ от направления иностранных (международных) наблюдателей за выборами.

${ }^{2}$ Муссави утверждал, что он набрал 65\% голосов избирателей. 
Ирана ${ }^{1}$. Из 475 соискателей Советом стражей были утверждены лишь 4 благочестивых кандидатамусульманина $^{2}$. Для претендентов на выборную должность приоритетное значение имеет позиция Высшего Руководителя Ирана ${ }^{3}$. Религиозный фактор учитывался оппозиционными силами при осуществлении предвыборной агитации и обжаловании результатов выборов. Сторонники Муссави своим политическим цветом избрали традиционный для мусульман зеленый цвет ${ }^{4}$. Требования Муссави отменить результаты выборов сочетались с его призывами уважать мусульманскую систему ценностей Исламской Республики. В связи с массовыми беспорядками, вспыхнувшими после объявления результатов выборов, высшие духовные лица использовали свое влияние для консолидации общества и стабилизации общественно-политической обстановки. Аятолла Али Хаменеи 19 июня 2009 г. обратился к нации, подчеркнул легитимность результатов состоявшихся выборов, потребовал прекратить незаконные уличные демонстрации и обвинил Запад в развязывании агрессивной политической кампании против Исламской Республики Иран. Мнение духовенства имело ключевое значение при решении вопроса об аннулировании результатов состоявшихся выборов. 23 июня 2009 г. именно Совет стражей принял решение об отказе в отмене результатов выборов и отсрочке официального опубликования результатов выборов в связи с необходимостью проверки поступивших жалоб.

1 Совет стражей конституции является органом конституционного контроля Исламской Республики Иран. Он состоит из 6 представителей духовенства, назначаемых Высшим Руководителем, и 6 судей, назначаемых главой Верховного Суда. В соответствии со статьей 115 Конституции Ирана Совет стражей осуществляет проверку кандидатов на выборные должности (Президента и депутатов Меджлиса) на религиозную благочестивость, проверяет соответствие законопроектов нормам шариата и рассматривает жалобы об итогах голосования и результатах выборов. Под давлением оппозиции 27 июня 2009 г. Совет стражей принял антиконституционное решение о делегировании части своей компетенции специальной комиссии для выборочной проверки 10\% избирательных бюллетеней. Необходимо отметить, что в ходе «оранжевой» революции Верховный Суд Украины принял не предусмотренное законом решение об отмене результатов президентских выборов во втором туре, а ЦИК Украины было принято незаконное решение о переголосовании второго тура выборов 26 декабря 2004 г.

${ }^{2}$ Согласно Конституции Исламской Республики Иран кандидатом в Президенты может стать гражданин Ирана с опытом в политике и религиозным воспитанием, который верит в принципы Исламской Республики Иран и придерживается официальной религии государства.

${ }^{3}$ Высший Руководитель Ирана избирается пожизненно Советом Экспертов, состоящим из 86 представителей духовенства. Высший Руководитель определяет основные направления внутренней и внешней политики государства, решает вопросы войны и мира, назначает половину состава Совета стражей конституции, является Главнокомандующим Вооруженными Силами Ирана, назначает командующих Вооруженными Силами, внутренними войсками, командующего Корпусом стражей исламской революции, судей высших судебных инстанций, подписывает указ о назначении избранного Президента и осуществляет опеку над системой государственной власти исламской Республики. В 2009 г. при выдвижении и регистрации кандидатов на должность Президента Высший руководитель Ирана аятолла Али Хаменеи поддержал Махмуда Ахмадинежада.

4 Примечательно, что газета «Кейхан» отметила сходство этой технологии с «цветными» революциями на постсоветском пространстве и указала на неэтичность использования в политических целях священного цвета ислама. 
Во-вторых, для «иранского» варианта было характерно использование как официальными властями, так и оппозиционными силами современных информационных технологий. В условиях состоявшихся президентских выборов кандидаты впервые участвовали в теледебатах в прямом эфире. В ходе осуществления предвыборной агитации, а также для последующей мобилизации отдельных групп населения на участие в массовых демонстрациях протеста силами оппозиции широко использовались электронные СМИ, возможности сети «Интернет». В связи с необходимостью противодействия эскалации насилия и локализации массовых беспорядков официальные власти провели кратковременное отключение мобильных сетей, ограничили доступ к ряду сайтов (например, к сайту Би-би-си) и заблокировали отправку SMS - сообщений. Представители иностранных СМИ были лишены возможности ведения репортажей с места событий, ряд из них был выслан из страны в административном порядке ${ }^{1} .22$ июня в Парламенте (Меджлисе) обсуждался вопрос о выдворении из страны западных дипломатов ${ }^{2}$. Министр иностранных дел Ирана Моттаки отказался от посещения конференции по Афганистану, проводимой 25-27 июня в рамках встречи министров иностранных дел стран «Большой восьмерки». Однако, несмотря на предпринятые властями Ирана жесткие меры, установить полный контроль за информационным пространством не удалось ${ }^{3}$. Пользователи Интернета выкладывали фотографии и видеозаписи с мобильных телефонов в социальных сетях «Twitter» и «Facebook». Иностранные СМИ тиражировали видеоролики, размещенные на online-портале «Youtube». Блоггеры и другие персональные пользователи преодолевали государственный контроль трафика с помощью софта «Freegate».

В-третьих, немаловажную роль в иранской «зеленой» революции сыграла половозрастная составляющая электората. Социальную базу протестных выступлений и сторонников оппозиции составили представители студенческой молодежи, творческой интеллигенции и молодые женщины ${ }^{4}$. Эти люди выразили свое недовольство засилием консервативного духовенства, отчуждением политического руководства от народа, социально-экономическими условиями жизни в стране, положением женщин и молодежи, закрытостью иранского общества.

В-четвертых, обращает на себя внимание непривычная для «цветных» революций национал-консервативная ориентация политических программ основных соперников - кандидатов

${ }^{1}$ В ходе президентских выборов 2005 г. в Иране иностранные СМИ, осуществляющие теле- и радиовещание на фарси, призывали избирателей бойкотировать голосование, «чтобы не придавать иранскому режиму легитимность».

${ }^{2}$ В связи с активным участием в массовых беспорядках силами безопасности было задержано несколько сотрудников посольства Великобритании из числа граждан Ирана.

3 В соответствии с Законом 2006 г. максимальная скорость предоставления трафика персональным пользователям сети Интернет в Исламской Республике Иран составляет 128 Кб/с.

${ }^{4}$ Средний возраст граждан Ирана составляет 25-27 лет. Более 60\% населения Исламской Республики представлено молодежью в возрасте до 30 лет. 
в Президенты ${ }^{1}$. Дело в том, что космополитические и откровенно «прозападные» либеральные установки политиков в Иране заведомо обречены на поражение. Осознавая это обстоятельство, оба главных кандидата в Президенты в предвыборных дебатах критиковали Соединенные Штаты, отстаивали необходимость создания независимого палестинского государства, обосновывали значимость иранской «атомной» программы и недопустимость приватизации иностранными инвесторами стратегических отраслей и объектов национального промышленного сектора. Тем не менее, идейно-политическая платформа Муссави выглядела для США и их союзников более привлекательной, поскольку лидер оппозиции выступал за разрядку, диалог с Западом, прозрачность в осуществлении «атомной» программы, расширение прав женщин, признавал и осуждал Холокост ${ }^{2}$. Позиционируя себя в качестве «консерватора-реалиста», Муссави даже предложил ликвидировать религиозную полицию.

Кому же была выгодна «цветная» революция в Иране, кто стоял за широко рекламируемыми протестными акциями «иранского народа»?

С геополитической точки зрения, смена власти в Иране нужна была, прежде всего, Соединенным Штатам и их союзникам (ЕС и Израилю).

Для стран Запада победа Ахматинежада означает консервацию теократического режима с элементами авторитаризма, усиление претензий на лидерство в мусульманском мире, форсирование «атомной» программы и ирано-израильскую войну. Победа же Муссави предполагает отказ иранского руководства от позиций радикального фундаментализма, снижение актуальности «палестинского», «ливанского», «израильского» вопросов, создает условия для допуска иностранных кампаний и частных инвесторов в национальные отрасли экономики, позволяет сосредоточить усилия на постепенном установлении внешнего контроля над топливно-энергетическим сектором и создании гарантий европейской энергобезопасности, поэтому в глазах западных политиков представляется предпочтительной.

Использованная в Иране попытка смены политического режима, основанная на актуализации проблемы легитимности выборных представительных органов, осуществлялась в строгом соответствии с американской технологией формирования во всех стратегических регионах мира зависимых политических режимов c контролируемой системой органов государственной власти и отвечающей национальным интересам США системой законодательства. По сообщениям иранского информационного агентства «Ирна», информация о подготовке «цветной» революции при

${ }^{1}$ В ходе «цветных» революций в 2000 г. в Сербии, в 2003 г. в Грузии, в 2004 г. в Украине оппозиция сама называла себя «прозападной». Не случайно надписи на плакатах демонстрантов и участников массовых беспорядков были выполнены не на родном, а на английском языке.

${ }^{2}$ О либерализме Муссави говорить не приходится, так как в период с 1981 по 1989 гг., когда он занимал пост премьер-министра Ирана, продолжались репрессии, осуществлялись массовые казни, были закрыты многочисленные СМИ. При нем же была начата и «атомная» программа. 
поддержке США была известна руководству Исламской Республики еще до проведения голосования. 5 июня командующий центральным военным округом Корпуса стражей исламской революции «Сепах» генерал Али Асгар Хани обвинил оппозицию в подготовке «цветной» революции по примеру Грузии и Украины. После начала массовых беспорядков МВД Ирана сообщило о получении демонстрантами поддержки от США (в частности, организационно-методической помощи от ЦРУ). По данным информационного агентства новостей «Фарс», многие манифестанты были материально вознаграждены за участие в акциях протеста. На «американский» след в этой истории также указывает развязанная иностранными (прежде всего, англоговорящими) СМИ массовая информационная истерия по поводу беспорядков в Тегеране, которая подозрительно напомнила умело организованные Вашингтоном антироссийские пропагандистские операции времен «холодной войны» ${ }^{1}$. По словам пресс-секретаря МИД Ирана Хасана Кашкави, журналисты Би-би-си и радиостанции «Голос Америки» делали все возможное для «активизации расовых и этнических разногласий в Иране» и «дезинтеграции иранского народа»².

Существенным отличием американской политики установления лояльных политических режимов после прихода к власти Б. Обамы стала политическая гибкость, связанная с отказом от прямого вмешательства в обсуждение результатов избирательной кампании и завуалированной ролью США в иранской «зеленой» революции. В этот раз руководство США до проведения выборов не заявляло об их нелигитимности, официально не высказывалось о результатах выборов и не называло «законных» победителей.

С внутриполитической точки зрения, смена власти в Исламской Республике отвечала интересам ряда влиятельных представителей политических элит Ирана. В условиях президентской избирательной кампании 2009 г. произошло столкновение лидеров консервативного и реформаторского лагерей в высшем руководстве страны, за которыми стояли последователи Али Хаменеи, с одной стороны, и Хомейни, с другой. Выразителем взглядов консервативного лагеря исламских фундаменталистов стал Ахмадинежад, поддержанный аятоллой Ахмадом Хатами и Высшим Руководителем Ирана аятоллой Али Хаменеи. На стороне реформаторского лагеря, объединяющего представителей творческой интеллигенции, предпринимателей и часть землевладельцев, выступил Муссави. Его кандидатура нашла поддержку аятолл Хуссейна Али Монтазери, Насера Ширази, Мусави Ардебили, бывших Президентов Ирана Абдул Хасана Баниссадра, Хашеми Рафсанджани, Мохаммада Хатами и председателя Меджлиса Али Лариджани. Сам Ахмадинежад назвал главой заговора оппозиции аятоллу Хашеми Рафсанджани, который «после исламской революции сделал себя и членов своей семьи миллиардерами»³.

1 Аналогичные информационно-пропагандистские акции предпринимались англоговорящими СМИ в августе 2008 г. в условиях грузино-абхазского конфликта. Тогда осуществлялись попытки представить грузинских агрессоров в роли невинных «жертв» российского «нападения».

${ }^{2}$ См.: Рос. газ. 2009. 23 июня.

${ }^{3}$ См. Рос. газ. 2009. 15 июня. 
После поражения Муссави на выборах вспыхнувшие в иранской столице массовые беспорядки стали удобным инструментом внешне- и внутриполитической дипломатии. Для Соединенных Штатов и Евросоюза акции протеста явились поводом напомнить мировому сообществу о необходимости соблюдения основополагающих прав и свобод человека и гражданина, а также активизировать дискуссию о демократизации политической системы Ирана. Для Израиля - основанием обвинить Ахмадинежада в политических репрессиях и поддержке терроризма ${ }^{1}$. Для проигравших лидеров иранской оппозиции массовые волнения стали возможностью мобилизовать сторонников, привлечь внимание общественности к своим политическим программам, скорректировать требования в части проведения новых выборов, а также заявить о своих серьезных притязаниях на участие в управлении государством.

Следует иметь в виду, что за достижением официально декларируемых оппозицией целей стоит решение скрытых задач, поставленных Администрацией Белого Дома.

Задачей - максимум «зеленой» революции в Иране является ликвидация монопольного влияния высшего духовенства на политическую и финансовую системы Исламской Республики с последующей переориентацией государства на Запад ${ }^{2}$, задачей - минимум - техническое отстранение аятоллы Али Хаменеи и его ставленников в органах государственной власти ${ }^{3}$. В рамках решения этих задач лидерами оппозиции (в частности, Рафсанджани) проводились тайные переговоры с представителями шиитского духовенства в теологическом центре - г. Кум, предпринимались попытки привлечь известных религиозных деятелей и правоведов на сторону оппозиции. В ряде случаев это удалось сделать. Так, аятолла Хуссейн Али Монтазери 16 июня подверг резкой критике фальсификации на выборах и поставил под сомнение легитимность сформированных органов власти. В поддержку Муссави также выступила группа религиозных деятелей из либерального объединения «Роханиюн Мобариз» ${ }^{4}$.

События, произошедшие в Тегеране после президентских выборов 2009 г., продемонстрировали всему миру эффективные возможности использования технологий «цветных» революций для расшатывания конституционного строя даже в консервативных религиозных государствах.

Ясно, что после президентских выборов внутриполитическое развитие Ирана не будет столь однородным, как прежде. Высшему руководителю и выстроенным под него органам государственной власти (прежде всего, Президенту) придется искать пути снижения социальной напряженности в обществе и раскола социальной базы оппозиции. В этой связи возможны тактические уступки со стороны Хаменеи и проведение частичных реформ (прежде всего, в социально-экономической сфере), не затрагивающих фундаментальные основы Исламской Республики. С учетом необходимости обеспечения

1 Заместитель министра иностранных дел Израиля Дани Аялон заявил, что исход выборов в Иране выражает растущую угрозу, которую необходимо остановить.

2 За отделение церкви от государства выступает и часть иранских религиозных деятелей (например, Хассан Юсефи Эшкевари).

${ }^{3}$ На роль Высшего Руководителя Ирана претендует Хашеми Рафсанджани.

${ }^{4}$ См. Рос. газ. 2009. 15 июня. 
независимости страны от сырьевой коньюнктуры следует ожидать увеличения государственных инвестиций в инфраструктуру и отдельные перерабатывающие отрасли экономики, реализации мер по созданию новых рабочих мест для молодежи ${ }^{1}$. Будет продолжаться активизация негосударственных элементов политической системы общества (политических партий, правозащитных структур, СМИ, неправительственных организаций), направленная на лоббирование интересов оппозиции.

Несмотря на попытки США, Израиля и Евросоюза увязать поражение оппозиции с проблемой официального признания избранного Президента, окончательная легитимация политической власти в Иране обусловлена инаугурацией Президента, а не признанием результатов национальных выборов из-за рубежа ${ }^{2}$. Очевидно, что недовольство заинтересованных иностранных государств выльется в «замораживание» сотрудничества, протесты министерств иностранных дел, осуждающие заявления парламентов, поучающие резолюции международных организаций, нападения на посольства Ирана. Возможны экономические санкции со стороны Соединенных Штатов (в частности, ограничение экспорта иранской нефти и ввоза бензина). Все эти действия будут очередным продолжением контрпродуктивной трансатлантической стратегии изоляции Ирана и повлекут за собой активизацию двусторонних связей Исламской Республики с Китайской Народной Республикой, Российской Федерацией, Республикой Беларусь, Венесуэлой, Шанхайской организацией сотрудничества.

Как представляется, современная практика межгосударственных отношений должна базироваться не на конфронтационных подходах «холодной войны», объявлении государств «изгоями», странами «оси зла», стремлением дипломатически изолировать их и подорвать конституционный строй с помощью «цветных» революций, а на принципах уважения государственного суверенитета и особенностей национальной общественно-политической системы.

Красинский Владислав Вячеславович кандидат юридических наук, эксперт Российского общественного института избирательного права (РОИИП)

Источник опубликования: Красинский В.В. Проблемы легитимации власти после президентских выборов в Иране // Современное право. 2010. № 1. С. 138-143.

${ }^{1}$ Официальный уровень безработицы в Иране составляет $17 \%$.

${ }^{2}$ В целях недопущения новых массовых акций оппозиции фиксированная дата инаугурации Президента не была назначена. Процедура вступления Президента в должность была ограничена периодом с 26 июля по 19 августа. 